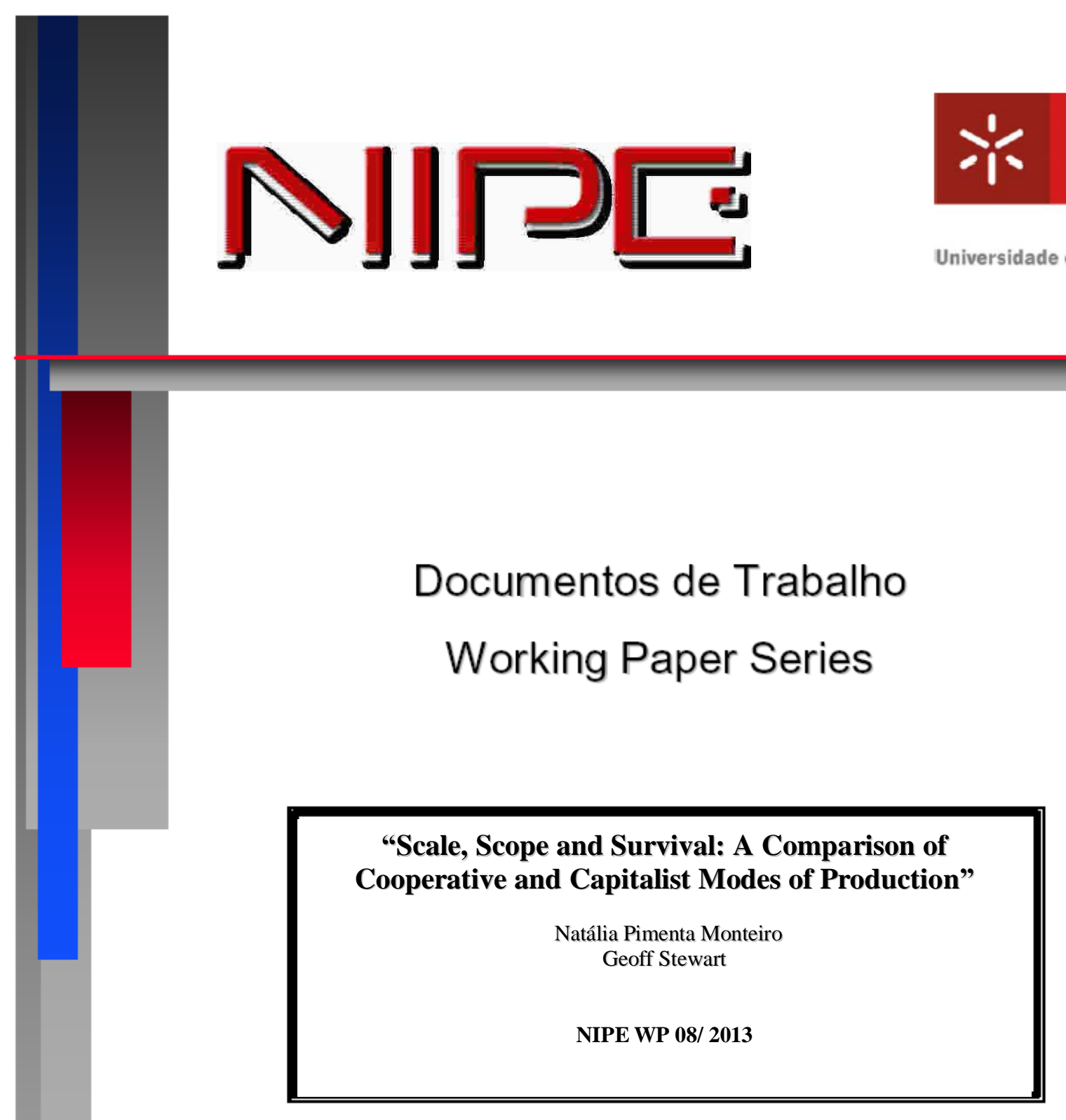

NÚCLEO DE INVESTIGAÇÃO EM POLÍTICAS ECONÓMICAS UNIVERSIDADE DO MINHO 


\section{"Scale, Scope and Survival: A Comparison of Cooperative and Capitalist Modes of Production"}

Natália Pimenta Monteiro

Geoff Stewart

NIPE* WP 08/ 2013

URL:

http://www.eeg.uminho.pt/economia/nipe
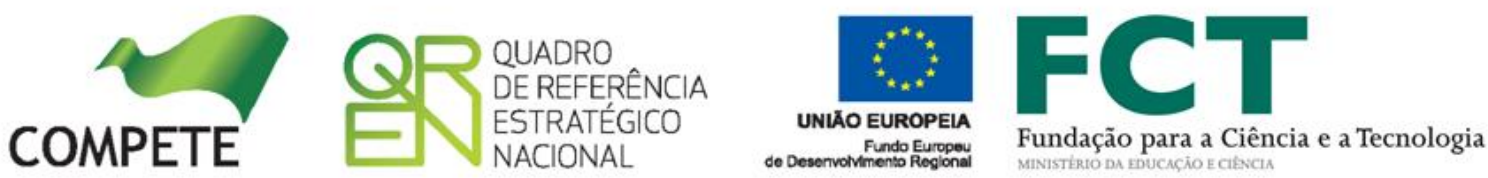


\title{
Scale, Scope and Survival: A Comparison of Cooperative and Capitalist Modes of Production*
}

\author{
Natália Pimenta Monteiro ${ }^{\dagger}$ and Geoff Stewart ${ }^{\ddagger}$
}

April 2013

\begin{abstract}
This paper draws on a comprehensive data set from Portugal to investigate the activities, internal characteristics and survival prospects of cooperatives and capitalist enterprises. Consistent with theory, high levels of market concentration and low entry costs were shown to be conducive to cooperatives. Cooperatives were found to be, on average, older and to operate with a larger, more highly educated and more productive labour forces than their capitalist counterparts. Finally, we show that cooperatives have a markedly higher probability of survival than capitalist enterprises, even after controlling for industry and firm characteristics.
\end{abstract}

JEL Classification: J54, P12

Keywords: Cooperatives; capitalist firms; firm ownership

${ }^{*}$ We thank the Ministério do Trabalho e da Solidariedade Social for allowing access to data from the Quadros de Pessoal. We are also grateful to the Portuguese Foundation for Science and Technology and Santander for financial support. The support from the Portuguese Foundation for Science and Technology was provided through the Programa Operacional Temático Factores de Competitividade (COMPETE) of the Quadro Comunitário de Apoio III, which is partially funded by FEDER.

${ }^{\dagger}$ Corresponding author. Department of Economics and NIPE, School of Economics and Management, University of Minho, Campus de Gualtar, 4710-057 Braga, Portugal. E-mail: n.monteiro@eeg.uminho.pt

${ }^{\ddagger}$ Economics Division, University of Southampton, UK. E-mail: gs@soton.ac.uk 


\section{Introduction}

A long-standing and fundamental question in economics is why firms in market economies are typically owned by the suppliers of capital. Interest in this question, and firm ownership more generally, has increased in recent years as a result of developments in the theory of the firm, the recognition that, notwithstanding the predominance of investor-owned enterprises, alternative organisational forms are present in significant numbers, and indications that advances in technology are leading to fundamental changes in the organisation of production. ${ }^{1}$

In this paper we focus on cooperatives as an alternative to investor ownership. Cooperatives, as Hansmann (1999) points out, are a relatively new form of organisation - having emerged as recently as the latter half of the nineteenth century - but now have a significant economic presence. Notable contemporary examples include Associated Press and Visa both of which are owned by consumers (media organisations and banks, respectively), the worker-owned cooperatives clustered around the town of Mondragon in the Basque region of Spain, which accounted for $8 \%$ of Basque industrial gross value added in 2008, and the farmer-owned cooperatives which are responsible for the marketing of substantial portions of agricultural output in many countries.

The question of why some firms are organised as cooperatives whilst others are investor owned has attracted the attention of theorists, with prominent hypotheses emphasising the roles of market power, risk, preference heterogeneity, access to finance and interpersonal trust (see, for example, Hansmann, 2012 and Hart and Moore, 1996). ${ }^{2}$ With the exception of Jones and Kalmi's (2009) analysis of the implications of geographical variations in the level of trust, econometric evidence is confined to a small number of studies focussing specifically on worker cooperatives. ${ }^{3}$ There is a scarcity even of basic comparative information on the characteristics and performance of the two types of organisation, with empirical evidence largely confined to informal analyses of particular markets (for example, Hansmann, 2012 on electricity distribution cooperatives in the US and Hart and Moore, 1996 on securities exchange cooperatives).

In this paper we draw on a comprehensive data set from Portugal to make three contributions to the empirical literature. First, we investigate the patterns of activity undertaken

\footnotetext{
${ }^{1}$ See, for example, Baker and Hubbard (2004) on the impact of computers on the ownership of assets in the trucking industry, Hart and Moore (1996) on changes in the ownership of securities exchanges and Morrison and Wilhelm (2008) on the demise of partnerships in investment banking.

${ }^{2}$ Whilst we are not aware of a formal theoretical model linking cooperative activity to levels of interpersonal trust, Jones and Kalmi (2009) cite a number of papers that provide arguments suggesting the existence of such a link.

${ }^{3}$ Recent comparative studies involving worker cooperatives include Arando et al. (2012), Pérotin (2006) and Podivinsky and Stewart (2012).
} 
by cooperatives and investor-owned ("capitalist") firms, and test the hypotheses that cooperatives are attracted to sectors characterised by high levels of market power and low risk. Second, we present findings on the scale of operation and internal characteristics of cooperatives and capitalist firms and test for differences across the two types of enterprise. Third, we examine the lifespans of the two types of organisation and, using a multivariate hazard model, test whether there is a difference in their probability of survival.

Our data set - the Portuguese Quadros de Pessoal - has a number of attractive features in the present context. ${ }^{4}$ First, it is a census of virtually all firms in the economy. Second, the Portuguese framework of commercial law specifically includes a cooperative legal form - the "Código Cooperativo" - and such firms can, along with capitalist firms, be identified in the Quadros de Pessoal. This allows the two types of enterprise to be examined under a common framework, with variables being defined and collected in a consistent manner. Third, it provides detailed internal information on each firm including the date of constitution, mode of formation and demise, industry of operation, and accurate measures of firm size. Finally, the data extend over a 13 year period from 1995 to 2007, during the course of which the fate of individual firms can be tracked. ${ }^{5}$

Our analysis reveals the presence of cooperatives in most sectors of the economy but also that their distribution across industries differs markedly from that of capitalist firms. The arguments of Hansmann (1996) and Hart and Moore (1996) that market power is conducive to cooperatives receives strong econometric support, as does the hypothesis that cooperatives offer less protection against risk in the form of sunk entry costs. Demand volatility, on the other hand, is revealed not be a deterrent to cooperatives. With regard to internal characteristics, cooperatives were found to operate with a larger, more highly educated and more productive labour forces than their capitalist counterparts. Finally, we show that cooperatives have a higher probability of survival than capitalist enterprises, even after controlling for industry and firm characteristics.

The remainder of the paper is organised as follows. The next section provides a definition of both cooperatives and capitalist modes of production, and describes the data. Section 3 investigates the industry distribution and internal characteristics of each type of firm. Our findings on survival are presented in Section 4 and a concluding section then completes the paper.

\footnotetext{
${ }^{4}$ The Quadros de Pessoal has been used extensively for the analysis of firms in aggregate but not, as far as we are aware, cooperatives.

${ }^{5}$ The period was chosen on grounds of consistency of the industrial classification (CAE Rev. 2.1).
} 


\section{Definitions and data}

A satisfactory comparative analysis of cooperative and capitalist production requires, first of all, a precise theoretical distinction between the two organisational forms and, second, a close correspondence between these theoretical entities and the types of enterprise identifiable in the data.

Following a framework suggested by Grossman, Hart and Moore, the organisational form of an enterprise can be defined in terms of the ownership of - and thereby the residual rights of control over - its non-human assets (Grossman and Hart, 1986; Hart, 1995; Hart and Moore, 1990, 1996). Whilst, in principle, a particular firm might be owned by anyone, in practice, as Hansmann (1996) points out, ownership is generally assigned to parties that have a transactional relationship with the firm, either as suppliers of an input or as consumers of its output. The former category can usefully be divided into three groups: suppliers of financial capital; suppliers of labour; and suppliers of any other inputs such as raw materials.

A capitalist firm can then be defined as an enterprise in which the rights to residual control are assigned to the suppliers of financial capital, and in proportion to the amount of capital supplied. These control rights would typically cover matters such as the choice of products and prices, and decisions on employment and investment. In practice, such rights might be exercised directly or indirectly through the appointment of specialist managers. In the latter case, the owners retain ultimate control through their right to dismiss the management.

In this framework, a cooperative can be defined as an enterprise in which the rights to residual control are assigned to one of the other (i.e. other than capital suppliers) contracting parties, and in which these "members" exercise control on the basis of one-member, one-vote. Once again, decision-making might be delegated to specialist managers.

Our data are derived from the Quadros de Pessoal, an annual survey produced by the Portuguese Ministry of Labour and Social Security. All firms that have one or more wage earners are included in the survey with the exception of firms engaged in certain aspects of public administration and domestic work. As mentioned earlier, the Quadros de Pessoal classifies firms according to their legal form, which enables us to identify both cooperative and capitalist firms.

Under Portuguese commercial law, the rules governing the operation of cooperatives are set out in Article 3 of the "Código Cooperativo", which draw on principles set down by the International Co-operative Alliance. Two of these principles, concerning "democratic management" and "autonomy and independence" indicate a close correspondence with the above theoretical definition of a cooperative. On the issue of democratic management, the Código states: "The co-operatives are democratic organizations managed by their members, 
which actively participate in the formularization of policies and in making decisions. The men and women who exert their functions as representatives are responsible to the members who elected them. In the co-operatives of the first degree, the members have equal rights to vote (one member, one vote), and co-operatives of other degrees are also organized in a democratic form." On the matter of autonomy and independence, the Código requires that if a cooperative were to seek external capital then it must do so in a manner that maintains its autonomy as a cooperative.

In addition to cooperatives, no fewer than 39 alternative organisational forms are identified in the Quadros de Pessoal. However, the vast majority of enterprises (97\%) fall into one of just three categories: sole proprietorship (Pessoa em nome singular ou empresário em nome individual), private limited liability company (Sociedade por Quotas) and public limited liability company (Sociedade anónima). Each of these three organisational forms can be considered a capitalist enterprise on the above definition. Thus a sole proprietorship, in which the ownership of assets and ultimate control rests in the hands of a single individual, is the classic capitalist firm of Alchian and Demsetz (1972). In limited liability companies, whether private or public, ultimate control rests in the hands of shareholders on the principle of one-share-one-vote. The shareholders are capital suppliers in the sense that they are entitled to the residual proceeds from the sale of the assets should the firm be liquidated. Thus such enterprises also correspond to the definition of a capitalist enterprise.

The Quadros de Pessoal excludes any organisation which does not employ at least one worker. To clean the data, we removed any firm (whether cooperative or capitalist firm) which reported zero revenue in all periods. We also excluded all enterprises engaged in agriculture, hunting, forestry or fishing on the grounds that there is general acceptance among users of the Quadros de Pessoal that these sectors are characterised by under-reporting. ${ }^{6}$ Finally, we paid careful attention to a firm's legal status. In some instances a firm was present in the data at dates $t$ and $t+k$ but absent in between. Such firms were retained provided their status at $t$ and $t+k$ was the same. All other firms were checked for consistency of status. If a firm's status was missing in one or more years then, provided it was constant in the other years, the missing entries were imputed. ${ }^{7}$

\footnotetext{
${ }^{6}$ Specifically, we exluded enterprises in Sections A and B of the NACE Industrial Classification (Rev.1.1).

${ }^{7} \mathrm{~A}$ number of firms changed their legal status more than once. It is possible that this might indicate a classification error and thus all results were checked for robustness to the exclusion of these firms.
} 


\section{Industry distributions and firm characteristics}

In this section we investigate the types of activity undertaken by cooperatives and capitalist firms, and examine their internal characteristics. We test for differences across the two types of firm in these dimensions and investigate whether the industrial distribution of cooperatives is consistent with theoretical arguments in the literature. We begin with a brief review of these arguments.

\subsection{Theoretical background: implications of ownership structure}

The theoretical literature has identified a number of potential links between a firm's ownership structure and its behaviour and performance. ${ }^{8}$ Here we restrict attention to arguments that can be addressed using our data set.

One long-standing argument is that due to the inherent divisibility of financial capital, investors in a capitalist enterprise are more able to spread risks than are the members of a cooperative. Thus, in the specific context of worker cooperatives, Meade (1972) wrote: "While property owners can spread their risks by putting small bits of their property into a large number of concerns, a worker cannot put small bits of effort into a large number of different jobs" and thus "we are likely to find cooperative structures in lines of activity in which the risk is not too great" (p. 426). ${ }^{9}$ Meade's argument can be applied to cooperatives more generally since, as Hansmann $(1999,2012)$ points out, cooperative members frequently have a greater proportion of transactions, relative to their wealth, tied to a single firm than do investors in capitalist firms. However, Hansmann also points to situations where ownership enables individuals to hedge risks. In such circumstances, cooperatives might have comparable risk-spreading properties to capitalist enterprises. Housing cooperatives, Hansmann (2012) suggests, are a case in point.

Two further arguments that have frequently been advanced to explain why cooperatives are far less numerous than capitalist firms are first, that they are more susceptible to problems associated with collective governance and second, that they face particular difficulties in raising external finance. On the former, Dow and Skillman (2007) and Hart and Moore (1996) present models in which cooperative members exhibit a greater degree of preference heterogeneity than investors in capitalist firms and, as a result, experience inefficiencies in

\footnotetext{
${ }^{8}$ See Hansmann (1996), the conributions by Grossman, Hart and Moore cited above and, for the specific case of worker cooperatives, Dow (2003).

${ }^{9}$ Podivinsky and Stewart (2007 and 2012) found that risk, measured by the variance of industry profit, acted as a barrier to worker cooperative entry into UK manufacturing industries. Dong and Bowles (2002) found that risk played an important role in workers' decisions on whether to buy shares in privatised Chinese enterprises.
} 
decision-taking. Hansmann (2012) similarly emphasises this issue and, as an illustration, points out that agricultural marketing cooperatives typically deal with just one type of crop.

The basis of the finance argument is simply that in the presence of adverse selection or moral hazard, agents will be reluctant to lend money to organisations in which they are unable to exercise any control. Cooperatives, by virtue of the fact that control is exercised by members other than suppliers of capital, will then face a higher cost of external capital. Indeed, in the specific case of worker cooperatives Vanek (1977) has argued that the problems associated with finance are so serious that "they offer an ample explanation of the comparative failure of these forms in history, ever since they were first conceived of by the writers of the eighteenth and nineteenth centuries" (1977, p. 187). ${ }^{10}$

The final potential determinant of the pattern of cooperative activity that we consider is market power. Hansmann (2012) argues that many producer and consumer cooperatives have been established in situations where their members would otherwise have been exposed to monopsony or monopoly power. As examples, he cites the agricultural marketing and electricity distribution cooperatives in the US. Hart and Moore (1996) present a formal model in which the efficiency of cooperatives relative to investor-ownership is shown to be inversely related to the degree of competition. In line with the model, they suggest that increasing competition is one of the factors behind proposals to reform the structure of some securities exchanges in the direction of outside ownership. ${ }^{11}$

\subsection{Basic data on industry distributions and firm characteristics}

We begin by examining the pattern of activities undertaken by cooperatives and capitalist firms (CFs), first at the broad sectoral level and then in more detail for manufacturing and services. ${ }^{12}$ Table 1 shows the numbers and proportions of firms of each type, averaged over the period 1995-2007, in each of the major sectors of the economy, and also the ratio of cooperatives to total firms in each sector. As noted above, the agriculture, forestry, hunting and fishing sectors are excluded from the comparison. ${ }^{13}$

\footnotetext{
${ }^{10}$ Podivinsky and Stewart (2007 and 2012) found that high levels of capital intensity acted as a barrier to worker cooperative entry into UK manufacturing industries.

${ }^{11}$ In their model, an increase in competition constrains the ability of a profit-maximising outside owner to raise price above marginal cost, but may have no effect on a consumer cooperative's pricing decision.

${ }^{12}$ For some historical background of the cooperative sector in Portugal, see Fernandes (2006).

${ }^{13}$ Firms are classified according to the Portuguese CAE (Rev.2.1) system of industrial classification which is equivalent to NACE (Rev.1.1).
} 
Table 1: Broad average industry distribution of firms, 1995-2007

\begin{tabular}{lrrrrc}
\hline \hline & \multicolumn{2}{c}{ Coops. } & \multicolumn{2}{c}{ CFs } & Coops./Total \\
\cline { 2 - 6 } & No. & $\%$ & No. & $\%$ & $\%$ \\
\hline Mining and quarrying & 1 & 0.09 & 887 & 0.37 & 0.11 \\
Manufacturing & 215 & 19.42 & 41,658 & 17.38 & 0.51 \\
Electricity, gas and water & 7 & 0.65 & 102 & 0.04 & 6.81 \\
Construction & 64 & 5.78 & 34,946 & 14.58 & 0.18 \\
Services & 817 & 74.06 & 162,064 & 67.62 & 0.51 \\
& & & & & \\
Total & 1,106 & 100.00 & 239,657 & 100.00 & 0.46 \\
\hline \hline
\end{tabular}

The table reveals, first of all, that services was by far the major area of activity for firms of both types. Almost three-quarters of cooperatives and around two-thirds of capitalist firms were to be found in the service sector. The next most important areas were manufacturing, which accounted for approximately $19 \%$ of cooperatives and $17 \%$ of capitalist firms, and construction for which the respective figures were $6 \%$ and $15 \%$. The remaining sectors mining and quarrying and electricity, gas and water - together accounted for less than $1 \%$ of firms of each type. It can thus be seen that, in comparison with investor-owned enterprises, cooperatives were overrepresented in services and manufacturing, and underrepresented in construction. A Pearson Chi-square test revealed that the overall pattern of activity of cooperatives and capitalist enterprises was significantly different at the $1 \%$ level.

Table 2 presents more detailed information on the manufacturing sector.

Table 2: Average distribution (over time) of firms within Manufacturing, 1995-2007

\begin{tabular}{lrrrrc}
\hline \hline & \multicolumn{2}{c}{ Coops. } & \multicolumn{2}{c}{ CFs } & Coops./Total \\
\cline { 2 - 6 } & No. & $\%$ & No. & $\%$ & $\%$ \\
\hline Food, beverages and tobacco & 151 & 70.55 & 4,974 & 11.94 & 2.97 \\
Clothing, textiles and leather & 12 & 5.66 & 10,300 & 24.72 & 0.12 \\
Wood and furniture & 2 & 1.04 & 4,235 & 10.17 & 0.05 \\
Printing and publishing & 22 & 10.39 & 2,750 & 6.60 & 0.82 \\
Chemicals and pharmaceuticals & 3 & 1.47 & 1,437 & 3.45 & 0.23 \\
Glass and ceramics & 3 & 1.40 & 3,087 & 7.41 & 0.10 \\
Mechanical and metal products & 9 & 4.12 & 8,721 & 20.93 & 0.11 \\
Electrical and electronics & 4 & 1.72 & 1,490 & 3.58 & 0.24 \\
Other & 8 & 3.65 & 4,665 & 11.20 & 0.16 \\
& & & & & \\
Total & 215 & 100.00 & 41,658 & 100.00 & 0.51 \\
\hline \hline
\end{tabular}

The table reveals a very high degree of concentration of cooperative activity, with some $70 \%$ of firms operating in the food, beverages and tobacco sector, and $10 \%$ printing and 
publishing. ${ }^{14}$ A further $6 \%$ were engaged in the manufacture of clothing, textiles and leather and $4 \%$ in mechanical and metal products. Whilst we are unable to distinguish different types of cooperative within our data, we note in passing that both printing and publishing and clothing, textiles and leather have previously been identified as important areas of activity for worker cooperatives (see, for example, Ben-Ner, 1988a).

The distribution of capitalist enterprises within manufacturing is quite different to that of cooperatives. Most noticeably, only $12 \%$ of the former were engaged in the production of food, beverages and tobacco, whereas clothing, leather and textiles and mechanical and metal products each accounted for more than $20 \%$ of firms. In broad terms, it can be seen that capitalist firms were more evenly spread than cooperatives across the spectrum of manufacturing. A Pearson Chi-square test confirmed, once again, that the two distributions are significantly different at the $1 \%$ level.

Information on the service sector is presented in Table 3.

Table 3: Average distribution (over time) of firms within Services, 1995-2007

\begin{tabular}{lrrrrr}
\hline \hline & \multicolumn{2}{c}{ Coops. } & \multicolumn{2}{c}{ CFs } & Coops./Total \\
\cline { 2 - 6 } & No. & $\%$ & No. & $\%$ & $\%$ \\
\hline Wholesale, retail and repairs & 328 & 40.02 & 80,269 & 49.53 & 0.41 \\
Hotels and restaurants & 13 & 1.61 & 28,706 & 17.71 & 0.41 \\
Transport and communications & 40 & 4.90 & 9,975 & 6.15 & 2.59 \\
Finance & 99 & 11.29 & 1,420 & 0.88 & 27.15 \\
Real estate & 92 & 11.29 & 23,304 & 14.38 & 2.65 \\
Public administration and defense & 1 & 0.07 & 1 & 0.00 & 50.00 \\
Education & 97 & 11.81 & 2,243 & 1.38 & 4.23 \\
Health and social work & 37 & 4.57 & 7,322 & 5.44 & 0.47 \\
Other & 111 & 13.62 & 8,824 & 5.44 & 0.51 \\
& & & & & \\
Total & 819 & 100.00 & 162,064 & 100.00 & 0.42 \\
\hline \hline
\end{tabular}

Cooperatives were found to be active in all subsectors, with the main concentrations being in wholesale, retail and repairs (40\%), education (12\%), finance (11\%), and real estate $(11 \%) .{ }^{15}$ Once again, capitalist firms exhibit a noticeably different pattern of activity, with a higher proportion of firms engaged in wholesale, retail and repairs (50\%) and in hotels and restaurants (18\%), and a lower proportion in education (1\%) and finance (1\%).

These differences in the patterns of activity within the service sector are, as was the case with manufacturing and the broad sectoral distribution, statistically significant at the

\footnotetext{
${ }^{14} \mathrm{~A}$ more detailed breakdown revealed that no cooperatives were engaged in the production of tobacco products.

${ }^{15}$ The "other" category includes, among other activities: arts, entertainment and recreation, repair of household goods and various personal services.
} 
$1 \%$ level. In Section 3.3 we will investigate the relationship between organisational form, industry characteristics and internal firm attributes within a multivariate framework. In the remainder of this section we discuss the selection and construction of the industry variables and present summary data on both industry and firm characteristics.

Our brief review of the theoretical literature pointed to market power, risk, and the costs of external finance and collective governance as potential determinants of the pattern of cooperative activity.

To capture variations in market power we employ the Herfindahl-Hirschman Index of market concentration, defined - as with the other industry variables below - at the 5 digit CAE (4 digit NACE) level.

We consider two measures of the risk associated with entering a particular line of activity. First, we construct a measure of demand volatility recently proposed by Cuñat and Merlitz (2012) in their analysis of the implications of volatility and labour market flexibility for comparative advantage. The variable is constructed by first determining, for each firm, the standard deviation of the annual growth rate of its sales, the latter being measured by the year-difference in sales. The volatility measure, Volatility, is then calculated as the employment-weighted average of these standard deviations across all firms in the industry. This measure, as Cuñat and Merlitz point out, is unaffected by any trend growth in firms' sales. ${ }^{16}$

Second, we employ a proxy for the sunk costs of entry and exit based on observed industry entry and exit rates. This approach has been used in the literature on entry and survival by, for example, Mata and Machado (1996) and more recently, Bernard and Jensen (2007). The premise is that, in steady state, entry and exit rates will covary with the level of sunk costs. Following Bernard and Jensen (2007), we utilize the following proxy which allows for the fact that industries might not be in equilibrium:

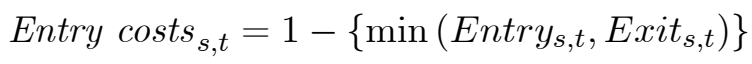

where Entry s,t $_{\text {is }}$ is the industry entry rate defined as the number of firms entering the industry during the period $t-1$ to $t$ divided by the total stock of firms at time $t$. Similarly, Exit $_{s, t}$ is the industry exit rate defined as the number of firms exiting the industry during the period $t$ to $t+1$ divided by the total stock of firms at time $t$.

We are not able to address the governance or finance arguments directly, nor do we have

\footnotetext{
${ }^{16}$ In line with the procedure adopted by Cuñat and Merlitz, we excluded any observation for which the absolute value of the growth rate exceeded $300 \%$.
} 
data on industry capital requirements. However, both arguments carry the suggestion that cooperatives might be more constrained in their scale of operation than capitalist firms, and we are able to examine the size distribution of each type of firm and to test whether minimum efficient scale affects the pattern of cooperative activity. Following Tsoukas (2011), minimum efficient scale, $M E S$, is proxied by the log of the median output in each sector.

Table 4 presents the mean values of each of these industry variables, together with the means of a set of internal firm attributes, for each enterprise type.

Table 4: Summary statistics, 1995-2007

\begin{tabular}{lrrrr}
\hline \hline Variables & Coops. & CFs & Observations & p-value \\
\hline Industry characteristics & & & & \\
Volatility & 0.54 & 0.47 & $3,129,909$ & 0.000 \\
Entry costs & 0.77 & 0.78 & $3,129,909$ & 0.000 \\
Concentration (HHI) & 0.08 & 0.03 & $3,129,909$ & 0.000 \\
log of MES & 12.36 & 11.77 & $3,129,909$ & 0.000 \\
& & & & \\
Firm characteristics & & & & \\
log of size (employment) & 2.15 & 1.31 & $3,129,909$ & 0.000 \\
Age & 25.57 & 8.63 & $3,129,909$ & 0.000 \\
log of labour productivity & 11.04 & 10.67 & $2,825,978$ & 0.000 \\
Average schooling (years) & 7.70 & 6.55 & $2,468,401$ & 0.000 \\
Proportion of men (\%) & 47.72 & 59.01 & $2,468,401$ & 0.000 \\
& & & & \\
Location (\%) & & & & \\
North & 27.14 & 35.62 & $3,129,909$ & 0.000 \\
Algarve & 4.86 & 5.23 & $3,129,909$ & 0.522 \\
Center & 23.08 & 22.34 & $3,129,909$ & 0.510 \\
Lisbon & 20.79 & 27.12 & $3,129,909$ & 0.000 \\
Alentejo & 17.01 & 6.20 & $3,129,909$ & 0.000 \\
Azores & 5.55 & 1.46 & $3,129,909$ & 0.000 \\
Madeira & 1.57 & 2.03 & $3,129,909$ & 0.169 \\
\hline \hline
\end{tabular}

Notes: The p-values refer to a test for significance of mean differences between cooperatives and capitalist firms. The data on worker attributes are missing in 2001.

The Table reveals first of all that, on average, cooperatives operate in markets characterised by higher levels of concentration, higher demand volatility, lower entry costs and higher minimum efficient scale than those populated by capitalist enterprises. These differences are all significant at the $1 \%$ level but, given that collinearity is to be expected, we defer any comments on the predictions from theory to the following section.

Second, it can be seen that there are significant differences in the internal attributes of the type types of firm. Specifically, cooperatives are, on average, older than capitalist enterprises and operate with a larger, more highly educated and more productive workforce. The average 
age of a cooperative is just over 25 years compared with less than 9 years for the average capitalist firm, and workers in the former have experienced, on average, one additional year of schooling. It can also be seen that there is a marked difference in gender make up of the workforces, with females forming the majority in cooperatives (52\%) but a minority $(41 \%)$ in capitalist enterprises.

The differences in the scale of operation of the two types of firm are set out in detail in Table 5.

Table 5: Firm size, 1995-2007

\begin{tabular}{|c|c|c|}
\hline & Coops. & CFs \\
\hline \multicolumn{3}{|c|}{ Number of employees } \\
\hline Mean & 23 & 10 \\
\hline \multirow{2}{*}{ Median } & 8 & 3 \\
\hline & \multicolumn{2}{|c|}{ Size distribution (\%) } \\
\hline $0-9$ & 54.09 & 83.29 \\
\hline $10-49$ & 35.98 & 14.32 \\
\hline $50-99$ & 5.87 & 1.43 \\
\hline $100+$ & 4.05 & 1.03 \\
\hline \multicolumn{3}{|c|}{ Annual revenue (millions of euros) } \\
\hline Mean & 3.619 & 0.972 \\
\hline \multirow[t]{2}{*}{ Median } & 0.350 & 0.116 \\
\hline & \multicolumn{2}{|c|}{ Size distribution (\%) } \\
\hline Less than 1 & 65.96 & 88.57 \\
\hline $1-2$ & 9.63 & 5.32 \\
\hline $2-3$ & 6.62 & 1.99 \\
\hline $3+$ & 17.78 & 4.12 \\
\hline Total & 14,370 & $3,115,539$ \\
\hline
\end{tabular}

We see from the table that cooperatives employed, on average, 24 workers, compared with an average of just 10 in capitalist enterprises. ${ }^{17}$ The data also reveal the presence of a significant number of medium and large cooperatives: almost $6 \%$ of cooperatives employed between 50 and 99 workers and a further $4 \%$ employed 100 or more. The corresponding proportions for capitalist firms can be see to be appreciably lower. Table 5 also shows that if size were to be measured by revenue rather than employment the differential is even more marked, with the average mean annual revenue in cooperatives being more than three and a half times the capitalist firm figure.

This finding that cooperatives are capable of operating on a large scale is not new as illustrated by the examples in the Introduction. Even in the case of worker cooperatives, which

\footnotetext{
${ }^{17}$ If sole proprietorships were excluded, the mean for capitalist firms would rise to 13 and the median to 4.
} 
one might expect to face the most severe constraints on size, Dow (2003, p.47) reports the existence of construction firms in Italy which employed about 3,000 workers and enterprises in the Mondragon group employing 200-300 workers. Indeed, Ben-Ner (1988a) reports that, in the 1980s, the mean employment level among Mondragon worker cooperatives exceeded 200 workers. We should note, however, that elsewhere the typical worker cooperative was considerably smaller: 27 workers, on average, in France and 40 in Italy. More recently, Burdín and Dean (2009) report that in Uruguay in 2005, the average worker cooperative employed 26 workers, which was almost twice the capitalist firm average.

\subsection{Econometric evidence}

We now examine the relationship between organisational form, firm attributes and industry characteristics within a multivariate framework. Specifically, we estimate the following logit model:

$$
\operatorname{Pr}\left(y_{i, t}=1 \mid x\right)=G\left(\beta^{s} x_{i, t}^{s}, \beta^{f} x_{i, t}^{f}, D_{s}, D_{r}, D_{t}\right)
$$

where $y_{i, t}$ takes the value 1 if firm ${ }_{i}$ is a cooperative and 0 if it is a capitalist firm, $x_{i, t}^{s}$ is a set of industry characteristics, $x_{i, t}^{f}$ is a vector of firm characteristics, and $D_{s}, D_{r}, D_{t}$ are sector, region, and year dummies respectively. ${ }^{1819}$

Table 6 reports the estimates from the model, using pooled data for the years 1995-2007. Column (1) presents the findings of a basic specification which incorporates only the industry variables and year fixed effects. Sector and region fixed effects, and then firm characteristics are successively introduced into the model and the findings reported in columns (2) - (5).

We begin with the industry variables and note, first of all, that they are consistent in sign across the specifications and, with the single exception of the entry cost proxy in column (1), significant at the $1 \%$ level.

The market concentration variable attracts a positive coefficient thus offering support for the arguments that market power is conducive to cooperatives The situation with regard to risk appears to be more complex. On the one hand, the negative coefficient on Entry costs would appear to suggest that cooperatives offer less protection against risk than capitalist enterprises whilst, on the other, the positive coefficient on Volatility indicates that cooperatives perform relatively well in markets characterised by high levels of demand variability. One possible explanation of these apparently contradictory findings is that the Entry costs

\footnotetext{
${ }^{18}$ The sector dummies are defined at the CAE 1-letter level (NACE 2-digit level).

${ }^{19}$ Exploration of differences in the regional distributions of the two types of firm is beyond the scope of the present paper. For recent work in this area see Arando et al. (2012), Jones and Kalmi (2009) and Kalmi (2012).
} 
variable might be picking up the effect of the hypothesised difference in the cost of raising finance for the two types of firm as well as in their risk-spreading properties.

Table 6. Multivariate logit of Cooperatives on characteristics

\begin{tabular}{|c|c|c|c|c|c|}
\hline & $(1)$ & $(2)$ & $(3)$ & $(4)$ & $(5)$ \\
\hline \multicolumn{6}{|l|}{ Industry characteristics } \\
\hline Volatility & $\begin{array}{r}1.509^{* * *} \\
(.106)\end{array}$ & $\begin{array}{r}1.431^{* * *} \\
(.110)\end{array}$ & $\begin{array}{r}1.495^{* * *} \\
(.111)\end{array}$ & $\begin{array}{r}1.822^{* * *} \\
(.122)\end{array}$ & $\begin{array}{r}1.819^{* * *} \\
(.126)\end{array}$ \\
\hline Entry costs & $\begin{array}{r}-0.267 \\
(.155)\end{array}$ & $\begin{array}{r}-1.062^{* * *} \\
(.120)\end{array}$ & $\begin{array}{r}-1.217^{* * *} \\
(.121)\end{array}$ & $\begin{array}{r}-1.797^{* * *} \\
(.134)\end{array}$ & $\begin{array}{r}-1.892^{* * *} \\
(.137)\end{array}$ \\
\hline Concentration (HHI) & $\begin{array}{r}2.465^{* * *} \\
(.143)\end{array}$ & $\begin{array}{r}1.627^{* * *} \\
(.158)\end{array}$ & $\begin{array}{r}1.655^{* * *} \\
(.159)\end{array}$ & $\begin{array}{r}1.439^{* * *} \\
(.186)\end{array}$ & $\begin{array}{r}1.390^{* * *} \\
(.195)\end{array}$ \\
\hline $\log$ of MES & $\begin{array}{r}0.461^{* * *} \\
(.029)\end{array}$ & $\begin{array}{r}0.510^{* * *} \\
(.024)\end{array}$ & $\begin{array}{r}0.507^{* * *} \\
(.024)\end{array}$ & $\begin{array}{r}0.287^{* * *} \\
(.031)\end{array}$ & $\begin{array}{r}0.295^{* * *} \\
(.032)\end{array}$ \\
\hline \multicolumn{6}{|l|}{ Firm characteristics } \\
\hline $\log$ of size & - & - & - & $\begin{array}{r}0.182^{* * *} \\
(.024)\end{array}$ & $\begin{array}{r}0188^{* * *} \\
(.026)\end{array}$ \\
\hline Firm age & - & - & - & $\begin{array}{r}0.137^{* * *} \\
(.005)\end{array}$ & $\begin{array}{r}0.141^{* * *} \\
(.005)\end{array}$ \\
\hline Firm age squared & - & - & - & $\begin{array}{r}-0.001^{* * *} \\
(.0001)\end{array}$ & $\begin{array}{r}-0.001^{* * *} \\
(.0001)\end{array}$ \\
\hline log of labour productivity & - & - & - & $\begin{array}{r}0.080^{* * *} \\
(.029)\end{array}$ & $\begin{array}{r}0.062^{* *} \\
(.030)\end{array}$ \\
\hline Average education & - & - & - & - & $\begin{array}{r}0.062^{* * *} \\
(.010)\end{array}$ \\
\hline Proportion of men & - & - & - & - & $\begin{array}{r}-0.881^{* * *} \\
(.085)\end{array}$ \\
\hline Year fixed effects & Yes & Yes & Yes & Yes & Yes \\
\hline Industry fixed effects & No & Yes & Yes & Yes & Yes \\
\hline Regional fixed effects & No & No & Yes & Yes & Yes \\
\hline Observations & $3,129,909$ & 3, 129, 909 & $3,129,909$ & $2,825,978$ & $2,258,506$ \\
\hline
\end{tabular}

Notes: Significance levels: $\quad *: 10 \% \quad * *: 5 \% \quad * * *: 1 \%$. Standard errors clustered at firm level.

The final industry variable, $M E S$, has a positive and significant coefficient even after controlling individual firm size. One way to interpret this finding would be to argue, following Audretsch and Mahmood (1995), that the greater the extent to which a firm is operating below minimum efficient scale, the greater will be its cost disadvantage. The positive coefficient on $M E S$ after controlling for size would then indicate that cooperatives were at less of a disadvantage than capitalist firms when operating at a suboptimal scale. However, we treat the MES finding with caution, first because of the inherent difficulty in measuring minimum efficient scale and, second, because our measure is based almost entirely on the capitalist 
enterprises within the sample.

Turning now to the firm attributes, all of the estimates are, in terms of sign, in line with the simple summary statistics presented above. Thus we find that, even in the presence of industry and firm controls, the probability of a randomly selected firm being organised as a cooperative is increasing in firm age and size, and the average educational level and productivity of its workforce, and decreasing in the proportion of males among its employees. The finding on productivity is consistent with a number of empirical studies (see, for example, Dow, 2003 and Maietta and Sena, 2010). ${ }^{20}$ In the following section we consider the implications of this and the other firm attributes on firm survival.

\section{Firm survival}

We saw in the previous section that the average age of cooperatives was greater than that of capitalist firms and that, even after controlling for a variety of firm and industry characteristics, the probability of a randomly selected firm being organised as a cooperative was increasing in the age of the firm. ${ }^{21}$ In this section we provide a detailed comparative analysis of the survival prospects of the two organisational forms. We begin with a review of the literature on firm survival, focussing on aspects which can be addressed using our data set. Kaplan-Meier survival functions for cooperative and capitalist firms are presented in Section 4.2 , which reveal that, at all age points, cooperatives are cumulatively more likely to have survived than capitalist firms. In Section 4.3 we undertake a detailed investigation of the probability of survival using a complementary log log proportional hazard model.

\subsection{Literature review}

As far as we are aware, the only theoretical arguments that explicitly address the survival prospects of cooperatives relative to capitalist firms relate to the survival of the particular organisational structure adopted by the enterprise rather than that of the production unit itself. One line of argument is that by setting up a capitalist firm, an entrepreneur is able to secure a larger share of the surplus than would be the case with a cooperative (see, for example, Ben-Ner, 1988b). In certain circumstances, the establishment and entry of the firm will, in itself, serve to consolidate the entrepreneur's position such that the future profit stream could then be realised by through the sale of the firm. At this stage, the

\footnotetext{
${ }^{20}$ The findings in Table 6 are robust to the use of an alternative estimation method (random-effects logit) which controls for firm unobserved heterogeneity in the panel dataset.

${ }^{21}$ The relationship is actually a quadratic. The probability of being a cooperative increases until the age of 71 years and then declines.
} 
ownership structure might change to reflect relative efficiency and thus some capitalist firms might become transformed into cooperatives. ${ }^{22}$ On the other hand, a prominent theme in the literature on worker cooperatives concerns the possibility such firms might display a tendency to "degenerate" into capitalist firms over time. The explanation is that there may be an incentive for a successful cooperative - in which income per worker exceeds the market wage - to replace any departing members with hired workers (Ben-Ner 1984, 1988b; Miyazaki 1984). ${ }^{23}$

The theoretical literature on firm survival more generally has focussed on the implications of age and size. Jovanovic (1982) presents a model in which firms are uncertain about their own efficiency, but learn through experience in the market. A high level of output signals a high level of relative efficiency with the implication of a positive association between firm size and the probability of survival. The age of the firm influences survival in two ways. First, the fact that experience enables the firm to estimate its cost of production with greater precision serves, other things being equal, to raise the probability of survival. However, due to an assumed convex relationship between expected future profit and expected relative efficiency, a firm's expected future profit, for given efficiency level, declines with the increased precision with which efficiency is estimated as the firm ages. This effect on expected future profit thereby generates a negative relationship between experience and survival and so the overall effect of age on survival cannot be signed a priori. ${ }^{24}$

Theoretical ambiguity also arises with regard to size once allowance is made for possible changes in the external environment. Thus, using an entirely different theoretical framework, Ghemawat and Nalebuff (1985) demonstrate that a large firm may have a greater incentive than a small firm to exit from a declining industry.

There is a large empirical literature on firm survival including two papers, Ben-Ner (1988a) and Pérotin (2004), with a specific focus on worker cooperatives. Ben-Ner estimated hazard rates, conditioned on age, for worker cooperatives and capitalist firms in the UK over the period 1974-86, and found that, at all age points, the cooperatives had a substantially lower probability of demise than capitalist firms. ${ }^{25}$ Pérotin (2004), examined the fortunes of a cohort of French enterprises over a period of up to 5 years from their formation in 1987. She found that, except at age 3 where the probabilities of failure were broadly similar, the

\footnotetext{
${ }^{22}$ See Stewart (1984) for a model in which an entrepreneur uses capital precommitment as a device for appropriating surplus and Hansmann (1996) for a discussion of owneship changes following entry. Hansmann recognises that, in practice, there may be impediments to changes in ownership structure.

${ }^{23}$ See Dow (2003) for further theoretical discussion of transformations and Abramitzky (2008) for an analysis of membership levels in the specific case of Israeli kibbutzim.

${ }^{24}$ See Dunne et al. (1989) and Pakes and Ericson (1998) for further discussion.

${ }^{25}$ Capitalist firm rates were based on data from 1974 to 1982 . Ben-Ner noted that the result was not sensitive to whether or not sole proprietorships were included in the set of capitalist firms.
} 
hazard rates of worker cooperatives were, once again, markedly below those of capitalist firms; after four years, nearly $75 \%$ of the cooperatives remained in operation compared with fewer than $60 \%$ of capitalist firms. Both papers also reveal a tendency for failure rates to decline over time, although for worker cooperatives, the evidence suggests there may be an initial phase of rising failure rates. Notwithstanding the theoretical ambiguities noted above, the wider literature on firm survival strongly suggests that both age and size have a negative impact on the probability of failure (see, for example, Agarwal and Gort (2002), Disney et al. (2003), (Mata and Portugal (2002) and Tsoukas (2011)). ${ }^{26}$ Two other firm attributes that are frequently included among the explanatory variables, and for which we have measures, are productivity and the skill or educational level of the workforce. These variables have similarly been found to have a negative effect on firm and plant exit (Bandick and Görg, 2010, Bernard and Jensen, 2007, Mata and Portugal, 2002).

A number of empirical studies investigate the role played by industry characteristics and, in fact, each of the industry attributes that we considered above in the context of the distribution of cooperative activity has been considered as a potential determinant of the likelihood of failure. Drawing on the work of Dunne et al. $(1988,1989)$, Bernard and Jensen (2007) emphasise the role of sunk entry costs and find, as expected, a significant negative relationship between their proxy measure and the probability of plant closure.

By contrast, no such clear-cut evidence has emerged with regard to demand volatility, minimum efficient scale or market concentration. Agarwal and Gort (2002) argue that demand volatility should increase failure rates but, in the absence of a direct measure of volatility, rely on the distinction between consumer and producer industries as a simple proxy. This proxy proves to be statistically insignificant.

The potential effects of minimum efficient scale and concentration are examined by $\mathrm{Au}-$ dretsch (1991) and Mata and Portugal (2002). Audretsch, noting the practical difficulty of measuring minimum efficient scale, constructs a proxy based on an approach suggested by Comanor and Wilson (1967). Mixed results were obtained, with the coefficient changing sign depending on the period of survival under consideration. Mata and Portugal (2002), employing the proxy suggested by Lyons (1980), found a significant positive relationship between minimum efficient scale and the probability of failure. The argument given by Audretsch for including market concentration among the set of regressors is that, to the extent that high concentration leads to high price-cost margins, it increases the survival prospects of those firms, typically new entrants, which are operating at a sub-optimal scale. Once again how-

\footnotetext{
${ }^{26}$ Studies of establishment or plant survival similarly find that age and size increases the chance of survival (see, for example, Bernard and Jensen, 2007 and Bandick and Görg, 2010). Disney et al. (2003) present results both for independent establishments and those which form part of a group under common ownership.
} 
ever, the available evidence does not offer strong support. Audretsch (1991) reports a positive and significant coefficient only when survival is measured over a short period following entry, whilst Mata and Portugal (2002) fail to detect a significant relationship.

\subsection{Empirical results}

We begin our analysis of firm survival by presenting, in Figure 1, Kaplan-Meier survival functions for all cooperatives and capitalist enterprises which were present in the data set at any time between 1995 and 2007. We are able to include firms that were created prior to 1995 as a firm's date of creation is collected as part of the census. The lifespan of each firm was computed as the difference between the last year that the firm was observed in the data set and the year the firm was constituted as reported in the data. Our interest here is in the survival of a production unit with a specific organisational form. All firms that changed legal status were therefore excluded from the survival analysis. In practice, almost all exits were due to dissolution; conversions accounted for only $6 \%$ of total cooperative failures and for a negligibly small proportion of capitalist firm failures. ${ }^{27}$

The survival functions show the percentage of firms of each type in the sample that had survived to, or beyond, the specified ages.

The figure reveals a clear difference in the lifespans of the two types of firms, which comes as no surprise given the earlier finding on the average age of the firms. It can be seen that, at every age point, cooperatives have a higher cumulative probability of survival. Approximately $97 \%$ of cooperatives in the sample had survived for 5 years or more, $84 \%$ had survived for 20 years or more and $63 \%$ had existed for 50 years or more. For capitalist enterprises the respective figures are approximately $80 \%, 45 \%$ and $20 \%$. It should be noted that the, perhaps surprisingly, long lifespans for enterprises of both types reflects the fact that the Kaplan-Meier methodology corrects for right censoring but not left censoring within the data; long-lived firms are over-represented.

To determine the factors underlying these differences, we estimated the following complementary log-log hazard model: ${ }^{28}$

$$
h_{i, t}=h_{0}(t) \exp \left(\beta^{\prime} Z(t)\right)
$$

\footnotetext{
${ }^{27}$ Our interest lies in the distinction between cooperatives and capitalist firms and so a change in status from sole proprietorship to company, or vice versa, is not regarded as a transformation.

${ }^{28}$ The cloglog model has been used by Bandick and Görg (2010) and Tsoukas (2011) and, as a discrete time version of the Cox proportional hazards model, is appropriate for the analysis of annual data. The underlying assumption of proportional hazard models is that the hazard depends only on the time at risk - the baseline hazard - and on explanatory variables affecting the hazard independently of time.
} 
Figure 1: Kaplan-Meier survival estimates

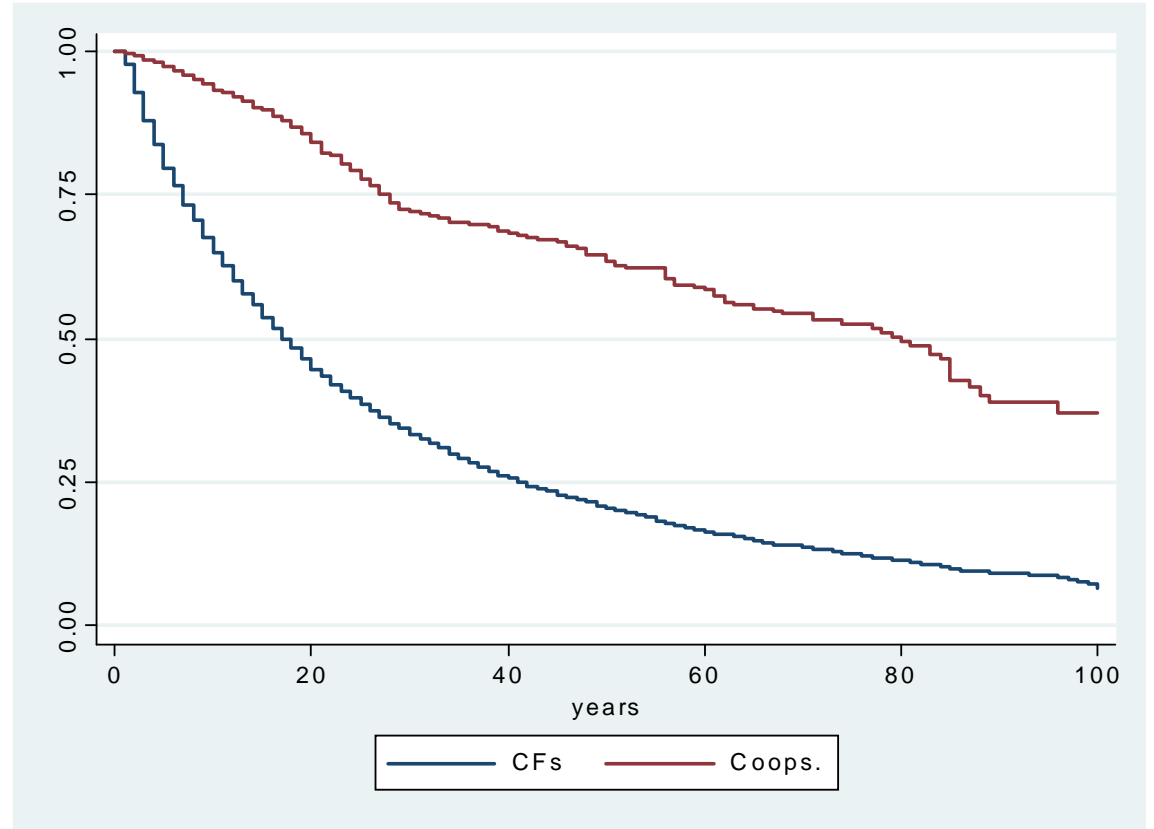

where $h_{i, t}$ is the probability that firm $i$ exits between dates $t$ and $t+1, t$ is the time since entry, $h_{0}(t)$ is the baseline hazard and $Z$ is a vector of explanatory variables.

The model was estimated using the full sample as above and the results are reported in Table 7. Note the dependent variable takes a value of 1 if the firm exits and 0 otherwise. In column (1) we report the estimated effect of cooperative ownership on the probability of failure, controlling only for the year of observation. As would be expected from findings in Figure 1, the coefficient is both negative and significant at the $1 \%$ level.

In columns (2) and (3) the four industry variables along with sector fixed effects and, in the case of column (3) regional fixed effects, are introduced alongside the dummy for cooperative ownership. ${ }^{29}$ This has the effect of reducing the magnitude of the coefficient on Coop, but only by a modest amount. As far as the industry variables themselves are concerned, all are significant with the positive coefficients on Concentration and Volatility, and the negative coefficient on Entry costs, conforming to a priori expectations and, in the latter case, the findings of Bernard and Jensen (2007). The role of minimum efficient scale is discussed below in the context of the firm attributes.

Columns (4) and (5) present the findings when the individual firm attributes are added, in two stages, to the specification. These two sets of results are very similar to each other

\footnotetext{
${ }^{29}$ Bernard and Jensen (2007) similarly include regional fixed effects in their examination of manufacturing plant closures.
} 
and we therefore restrict attention on the estimates from the full specification reported in column (5).

The first point to note is that whilst the inclusion of the firm attributes has the effect of further reducing the magnitude of the coefficient on Coop, it remains negative and highly significant. This represents the main finding to emerge from the hazard estimation.

Table 8. Determinants of Cooperative survival

\begin{tabular}{|c|c|c|c|c|c|}
\hline & (1) & (2) & $(3)$ & (4) & (5) \\
\hline Coop & $\begin{array}{c}-0.848^{* * *} \\
(.048)\end{array}$ & $\begin{array}{c}-0.711^{* * *} \\
(.048)\end{array}$ & $\begin{array}{c}-0.712^{* * *} \\
(.049)\end{array}$ & $\begin{array}{c}-0.234^{* * *} \\
(.052)\end{array}$ & $\begin{array}{c}-0.260^{* * *} \\
(.060)\end{array}$ \\
\hline \multicolumn{6}{|l|}{ Industry characteristics } \\
\hline Volatility & - & $\begin{array}{c}0.450^{* * *} \\
(.020)\end{array}$ & $\begin{array}{c}0.445^{* * *} \\
(.020)\end{array}$ & $\begin{array}{c}0.616^{* * *} \\
(021)\end{array}$ & $\begin{array}{c}0.725^{* * *} \\
(.025)\end{array}$ \\
\hline Entry costs & - & $\begin{array}{c}-0.831^{* * *} \\
(.028)\end{array}$ & $\begin{array}{c}-0.834^{* * *} \\
(.028)\end{array}$ & $\begin{array}{c}-0.705^{* * *} \\
(.031)\end{array}$ & $\begin{array}{c}-0.505^{* * *} \\
(.037)\end{array}$ \\
\hline Concentration (HHI) & - & $\begin{array}{c}-0.235^{* * *} \\
(.035)\end{array}$ & $\begin{array}{c}-0.213^{* * *} \\
(.035)\end{array}$ & $\begin{array}{c}-0.186^{* * *} \\
(.037)\end{array}$ & $\begin{array}{c}-0.275^{* * *} \\
(.045)\end{array}$ \\
\hline $\log$ of MES & - & $\begin{array}{c}-0.177^{* * *} \\
(.003)\end{array}$ & $\begin{array}{c}-0.174^{* * *} \\
(.003)\end{array}$ & $\begin{array}{c}0.088^{* * *} \\
(.004)\end{array}$ & $\begin{array}{c}0.098^{* * *} \\
(.005)\end{array}$ \\
\hline \multicolumn{6}{|l|}{ Firm characteristics } \\
\hline $\log$ of size & - & - & - & $\begin{array}{c}-0.683^{* * *} \\
(.003)\end{array}$ & $\begin{array}{c}-0.634^{* * *} \\
(.004)\end{array}$ \\
\hline Firm age & - & - & - & $\begin{array}{c}-0.023^{* * *} \\
\quad(.0005)\end{array}$ & $\begin{array}{c}-0.020^{* * *} \\
(.0005)\end{array}$ \\
\hline Firm age squared & - & - & - & $\begin{array}{l}0.000^{* * *} \\
(8.57 \mathrm{e}-06)\end{array}$ & $\begin{array}{c}0.000^{* * *} \\
(8.31 \mathrm{e}-06)\end{array}$ \\
\hline log of labour productivity & - & - & - & $\begin{array}{c}-0.152^{* * *} \\
(.003)\end{array}$ & $\begin{array}{c}-0.159^{* * *} \\
(.003)\end{array}$ \\
\hline Average education & - & - & - & - & $\begin{array}{c}0.021^{* * *} \\
(.001)\end{array}$ \\
\hline Proportion of men & - & - & - & - & $\begin{array}{c}-1.388^{* * *} \\
(.007)\end{array}$ \\
\hline Year fixed effects & Yes & Yes & Yes & Yes & Yes \\
\hline Industry fixed effects & No & Yes & Yes & Yes & Yes \\
\hline Regional fixed effects & No & No & Yes & Yes & Yes \\
\hline Observations & $2,692,505$ & $2,692,505$ & $2,692,505$ & $2,415,713$ & $1,896,373$ \\
\hline
\end{tabular}

Regarding the internal firm attributes themselves, the negative coefficients on age, size and productivity are consistent with the existing literature. It can also be seen that, once 
conditioned on firm size, the coefficient on minimum efficient scale has the expected positive sign. The estimates also point to a positive relationship between the average education of the workforce and the probability of failure, which is contrary to expectations, and to a negative association between the proportion of males and the probability of failure.

The main message to emerge, however, is that the earlier findings of Ben-Ner (1988a) and Pérotin (2004) on the superior survival prospects of worker cooperatives over capitalist enterprises also holds for cooperatives more generally. Furthermore, we have been able to demonstrate that differences in industry and firm characteristics account for some, but not all, of the superior performance of cooperatives in this respect. ${ }^{30}$

\section{Conclusions}

In this paper we have drawn on a comprehensive data set from Portugal to provide a detailed comparison of cooperative and capitalist modes of production. More specifically, we investigated the patterns of activity undertaken by cooperatives and capitalist firms, their scale of activity and internal characteristics, and ability to survive in the market.

The main findings of the paper are first, that there are significant differences in the industrial distribution of the two types of firm and that these differences reflect variations in market power and risk across industries. We found strong evidence in support of Hansmann's (1996) argument that cooperatives are attracted to markets with high levels of market power. The situation with regard to risk is less straightforward: cooperatives were less likely to be found in industries characterised by high entry costs, but were not deterred by high levels of demand volatility. In fact, the results point to a positive relationship between demand volatility and cooperative presence. These industry-level findings complement the work of Jones and Kalmi (2009) which focussed on the geographic distribution of cooperatives and found, at a country level, a positive relationship between the level of interpersonal trust and the presence of cooperatives.

Second, there were marked differences in the characteristics of the two types of firm. Cooperatives were typically older and larger, employing on average 24 workers compared with 10 workers in capitalist firms. Workers in cooperatives tended to be more highly educated and productive than their counterparts in capitalist firms.

Finally, we demonstrated that cooperatives enjoyed a higher probability of survival than

\footnotetext{
${ }^{30}$ The findings in Table 7 are robust to the use of an alternative estimation method (random-effects logit) which controls for firm unobserved heterogeneity in the panel dataset. We also estimated equations using a restricted sample comprising only those firms that entered the market during the period 1995-2007. This yielded qualitatively similar results except that the inclusion of the firm attributes led to a loss of significance of the coefficients on Coops and log MES. The signs on these coefficients were not affected.
} 
capitalist enterprises. In part this was due to differences between the firms in their industry distribution, age, size and other internal characteristics. However, even after controlling for these factors, cooperatives were found to have a higher probability of survival. Whether the explanation is simply that the costs that closure would generate for one of the classes of patrons - workers, consumers or suppliers - are internalised within a cooperative, or there are more complex factors involved, constitutes an interesting topic for further research.

\section{Bibliography}

Abramitzky, R. (2008). The limits of equality: insights from the Israeli kibbutzim. Quarterly Journal of Economics, 123, 1111-1159.

Agarwal, R. and Gort, M. (2002). Firm and product life cycles and firm survival. American Economic Review, 92, 184-190.

Alchian, A.A. and Demsetz, H. (1972). Production, information costs, and economic organization. American Economic Review, 62, 777-795.

Arando, S., Gago, M., Podivinsky, J.M. and Stewart, G. (2012). Do labour-managed firms benefit from agglomeration? Journal of Economic Behavior and Organization, 84, 1, 193-200.

Audretsch, D.B. (1991). New-firm survival and the technological regime. Review of Economics and Statistics, 60, 441-450.

Audretsch, D.B. and Mahmood, T. (1995). New firm survival: new results using a hazard function. Review of Economics and Statistics, 77, 97-103.

Baker, G.P. and Hubbard, N. (2004). Contractibility and asset ownership: on-board computers and governance in U.S. trucking. Quarterly Journal of Economics, 119, 1443-1479.

Bandick , R. and Görg, H. (2010). Foreign acquisition, plant survival, and employment growth. Canadian Journal of Economics, 43, 547-573.

Ben-Ner, A. (1984). On the stability of the cooperative form of organization. Journal of Comparative Economics, 8, 247-260.

Ben-Ner, A. (1988a). Comparative empirical observations on worker-owned and capitalist firms. International Journal of Industrial and Organization, 10, 287-313. 
Ben-Ner, A. (1988b). The life cycle of worker-owned firms in market economies. Journal of Economic Behavior and Organization, 6, 7-31.

Bernard, A.B. and Jensen, J.B. (2007). Firm structure, multinationals, and manufacturing plant deaths. Review of Economics and Statistics, 89, 193-204.

Burdín, G. and Dean, A. (2009). New evidence on wages and employment in worker cooperatives compared with capitalist firms. Journal of Comparative Economics, 37, 517-533.

Comanor, W.S. and Wilson, T.A. (1967). Advertising, market structure and performance. Review of Economics and Statistics, 49, 423-440.

Cuñat, A. and Merlitz, M.J. (2012). Volatility, labour market flexibility, and the pattern of comparative advantage. Journal of the European Economic Association, 10, 225-254.

Disney, R., Haskel, J. and Heden, Y. (2003). Entry, exit and establishment survival in UK manufacturing. Journal of Industrial Economics, 51, 91-112.

Dong, X. and Bowles, P. (2002). The determinants of employee ownership in China's privatised rural industry. evidence from Jiangsu and Shandong. Journal of Comparative Economics, 30, 415-437.

Dow, G.K. (2003). Governing the Firm: Workers' Control in Theory and Practice. Cambridge: Cambridge University Press.

Dow, G.K. and Skillman, G.L. (2007). Collective choice and control rights in firms. Journal of Public Economic Theory, 9, 107-125.

Dunne, T., Roberts, M.J., and Samuelson, L. (1988). Patterns of entry and exit in US manufacturing industries. RAND Journal of Economics, 19, 495-515.

Dunne, T., Roberts, M.J., and Samuelson, L. (1989). The growth and failure of U. S. manufacturing plants, Quarterly Journal of Economics, 104, 671-698.

Fernandes, M. (2006). Farm cooperatives and state policies in Portugal after the Carnations' Revolution. Paper presented at the XIV International Economic History Congress, Helsinki, Finland.

Ghemawat, P. and Nalebuff, B. (1985). Exit. RAND Journal of Economics, 16, 184-194.

Grossman, S.J and Hart, O.D. (1986). The costs and benefits of ownership: a theory of vertical and lateral integration. Journal of Political Economy, 94, 691-719. 
Hansmann, H. (1996). Ownership of Enterprise. Cambridge, MA.: The Belknap Press of Harvard University Press.

Hansmann, H. (1999). Cooperative firms in theory and practice. Finnish Journal of Business Economics, 4, 387-403.

Hansmann, H. (2012). Ownership and Organizational Form. In Gibbons, R. and Roberts,J. (Eds.) The Handbook of Organizational Economics. Princeton University Press: Princeton, 891-917.

Hart, O.D. (1995). Firms, Contracts and Financial Structure. Oxford: Clarendon Press.

Hart, O.D. and Moore, J. (1990). Property rights and the nature of the firm. Journal of Political Economy, 98, 1119-58.

Hart, O.D. and Moore, J. (1996). The governance of exchanges: members' cooperatives versus outside ownership. Oxford Review of Economic Policy, 12, 53-69.

Jones, D,C. and Kalmi, P. (2009). Trust, inequality and the size of the co-operative sector: cross-country evidence. Annals of Public and Cooperative Economics, 80, 165-195.

Jovanovic, B. (1982). Selection and evolution of industry. Econometrica, 50, 649-670.

Kalmi, P. (2012). Catching a wave: the formation of co-operatives in Finnish regions. Small Business Economics, forthcoming.

Lyons, B. (1980). A new measure of minimum efficient plant size in U.K. manufacturing industry. Economica, 17, 19-34.

Maietta O.W. and Sena, V. (2010). Financial constraints and technical efficiency: some empirical evidence for Italian producers' cooperatives. Annals of Public and Cooperative Economics, 81, 21-38.

Mata, J. and Machado, J.A.F. (1996). Firm start-up size: a conditional quantile approach. European Economic Review, 40, 1305-1323.

Mata, J and Portugal, P. (2002). The survival of new domestic and foreign-owned firms. Strategic Management Journal, 23, 323-343.

Meade, E.J. (1972). The theory of labour-managed firms and profit sharing. Economic Journal, 82, 402-428. 
Miyazaki, H. (1984). On success and dissolution of the labor-managed firm in the capitalist economy. Journal of Political Economy, 92, 909-931.

Morrison, A.D. and Wilhelm, Jr., W.J. (2008). The demise of investment banking partnerships: theory and evidence. Journal of Finance, 63, 311-349.

Pakes, A. and Ericson, R. (1998). Empirical implications of alternative models of firm dynamics. Journal of Economic Theory, 79, 1-46.

Pérotin, V. (2004). Early cooperative survival: The liability of adolescence. Advances in the Economic Analysis of Participatory and Labor-Managed Firms, 8, 67-86.

Pérotin, V. (2006). Entry, exit and the business cycle: are cooperatives different? Journal of Comparative Economics 34, 295-316.

Podivinsky, J.M. and Stewart, G. (2007). Why is labour-managed firm entry so rare? An analysis of UK manufacturing data. Journal of Economic Behavior and Organization, 63, 177-192.

Podivinsky, J.M. and Stewart, G. (2012). On the choice between capitalist and labourmanaged production: evidence from a panel of entrants into UK manufacturing industries. Advances in the Economic Analysis of Participatory and Labor-Managed Firms, 13, 77-95.

Stewart, G. (1984). Capitalists and workers: knowledge and the strategic role of investment within the firm. European Economic Review, 38, 1779-1797.

Tsoukas, S. (2011). Firm survival and financial development: evidence from a panel of emerging Asian economies. Journal of Banking and Finance, 35, 51736-1752.

Vanek, J. (1977). The Labor-Managed Economy. Ithaca, NY: Cornell University Press. 


\section{Most Recent Working Paper}

NIPE WP Monteiro, Natália Pimenta e Geoff Stewart "Scale, Scope and Survival: A Comparison of

08/2013 Cooperative and Capitalist Modes of Production", 2013

NIPE WP Esteves, Rosa-Branca e Joana Resende, "Competitive Targeted Advertising with Price

07/2013 Discrimination", 2013

NIPE WP Barbosa, Natália, Maria Helena Guimarães e Ana Paula Faria, "Single Market non-

06/2013 compliance: how relevant is the institutional setting?", 2013

NIPE WP Lommerud, Kjell Erik, Odd Rune Straume e Steinar Vagstad, "Mommy tracks and public

05/2013 policy: On self-fulfilling prophecies and gender gaps in promotion”, 2013

NIPE WP Brekke, Kurt R., Luigi Siciliani e Odd Rune Straume, "Hospital Mergers: A Spatial

04/2013 Competition Approach", 2013

NIPE WP Faria, Ana Paula e Natália Barbosa, “Does venture capital really foster innovation?”, 2013

$03 / 2013$

NIPE WP Esteves, Rosa Branca, “Customer Poaching with Retention Strategies”, 2013

$02 / 2013$

NIPE WP

$01 / 2013$

Aguiar-Conraria, Luís, Teresa Maria Rodrigues e Maria Joana Soares, "Oil Shocks and the

Euro as an Optimum Currency Area”, 2013

NIPE WP Ricardo M. Sousa, "The Effects of Monetary Policy in a Small Open Economy: The Case of

27/2012 Portugal" 2012

NIPE WP Sushanta K. Mallick e Ricardo M. Sousa, "Is Technology Factor-Neutral? Evidence from the US

26/2012 Manufacturing Sector" 2012

NIPE WP Jawadi, F. e Ricardo M. Sousa, "Structural Breaks and Nonlinearity in US and UK Public Debt"

$25 / 2012 \quad 2012$

NIPE WP Jawadi, F. e Ricardo M. Sousa, "Consumption and Wealth in the US, the UK and the Euro Area:

24/2012 A Nonlinear Investigation” 2012

NIPE WP Jawadi, F. e Ricardo M. Sousa, “ Modelling Money Demand: Further Evidence from an

23/2012 International Comparison" 2012

NIPE WP Jawadi, F. e Ricardo M. Sousa, "Money Demand in the euro area, the US and the UK:

22/2012 Assessing the Role of Nonlinearity" 2012

NIPE WP Agnello, L, Sushanta K. Mallick e Ricardo M. Sousa, "Financial Reforms and Income

21/2012 Inequality" 2012

NIPE WP Agnello, L, Gilles Dufrénot e Ricardo M. Sousa, "Adjusting the U.S. Fiscal Policy for Asset

20/2012 Prices: Evidence from a TVP-MS Framework t" 2012

NIPE WP Agnello, L e Ricardo M. Sousa, "Fiscal Adjustments and Income Inequality: A First

19/2012 Assessment" 2012

NIPE WP Agnello, L, Vitor Castro e Ricardo M. Sousa, "Are there change-points in the likelihood of a

18/2012 fiscal consolidation ending?" 2012

NIPE WP Agnello, L, Vitor Castro e Ricardo M. Sousa, "What determines the duration of a fiscal

17/2012 consolidation program?" 2012

NIPE WP Veiga, Linda, "Voting functions in the EU-15", 2012

$16 / 2012$

NIPE WP Alexandre, Fernando e Pedro Bação, "Portugal before and after the European Union: Facts on

$15 / 2012$ Nontradables", 2012

NIPE WP Esteves, Rosa Branca e Carlo Reggiani, "Behaviour-Based Price Discrimination with Elastic

14/2012 Demand", 2012

NIPE WP Afonso, Oscar, Sara Monteiro, Maria Thompson “ Innovation Economy, Productive Public

13/2012 Expenditures and Economic Growth ", 2012

NIPE WP Esteves, Rosa Branca “Price Discrimination with Private and Imperfect Information”, 2012

$12 / 2012$

NIPE WP Castro, Vítor "Macroeconomic determinants of the credit risk in the banking system: The case of

$11 / 2012$ the GIPSI", 2012

NIPE WP Bastos, Paulo, Natália Pimenta Monteiro e Odd Rune Straume "Privatization and corporate

$10 / 2012$ restructuring", 2012 